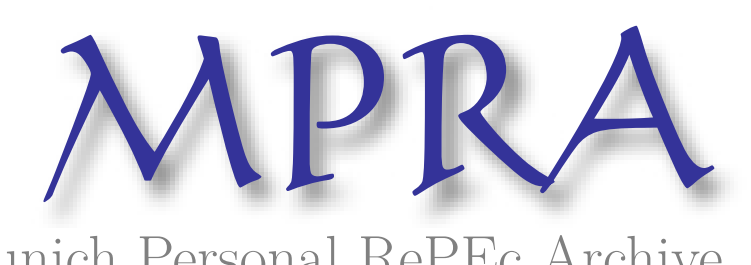

Munich Personal RePEc Archive

\title{
FOCUSING THE BALTIC AGRICULTURAL SECTOR TOWARDS THE NEW CONSUMER: ESTONIA'S CASE
}

van der Hoek, M. Peter and Chong, Yen Yee

Erasmus University Rotterdam

1996

Online at https://mpra.ub.uni-muenchen.de/6287/

MPRA Paper No. 6287, posted 20 Dec 2007 12:23 UTC 


\title{
FOCUSING THE BALTIC AGRICULTURAL SECTOR TOWARDS THE NEW CONSUMER: ESTONIA'S CASE
}

\author{
Yen Yee Chong and M. Peter van der Hoek ${ }^{\mathrm{i}}$
}

\section{Introduction}

This paper analyses some of the current problems emerging in the Baltic economies with special reference to Estonia and the agricultural sector. The prime objectives are to put forward suggestions for improving the agricultural investment, and to improve the marketing towards the modern international consumer. The major points covered are:

1.National changes following the break from USSR in 1991.

2.Re-orientation towards the European Union (EU) and international markets.

3. Changes for long-run growth in the Estonian agricultural sector.

4. Marketing, and training people to recognize and properly assess investment opportunities.

Estonia is a small country of 1.5 million people, with a per capita annual wage of approximately $\$ 2,100$. Independence was restored in 1991 within the Baltic states, but the agricultural slowdown continued. Estonian agricultural production fell by $21 \%$ in 1992 . However, the agricultural decline seems to have bottomed out. ${ }^{\text {ii }}$ Estonian agricultural output has stabilized in 1994, while a rise of 2\% is forecasted for 1995 (Estonian Economics Ministry, 1995). Resources are scarce for many nascent firms. Estonia, Latvia and Lithuania are examples of economies in transition, undergoing upheavals and moving from a centrally-planned system to a market economy.

Much of the macroeconomic change has stemmed from a re-orientation away from the former Soviet market and a focus on export of goods to the Western markets. Lithuania's exports to CIS countries decreased from 95\% of total exports in 1991 to 60\% in 1994 (Tamosiunas and Vilkas, 1995). The CIS share in Latvia's total exports has decreased to $43 \%$ in 1994 (Karnite et al., 1995), while Estonia has made even more progress in re-orienting to western markets. In 1994, Russia only accounted for $23 \%$ of Estonia's total exports (Lugus and Vitsur, 1995). This process of re-orientation is likely to gain in strength after the free trade association with the European Union (EU) came into effect as of January 1, 1995 and to the extent that more progress is made in the field of integration of the Baltic economies into the international markets.

The large fall in the agricultural production was partly because the Baltic area was somewhat of a "bread-basket", which provided much foodstuffs for the USSR. The break-up of the USSR, political instability, the fall in value of the ruble and the relatively new experience of exposure to world market competition, meant a huge loss in market share on the Russian market. 
Consequently, it may be expected that investment within the agricultural sector tends to fall until the marginal returns are equal to those returns in other industries. Other sectors, such as banking and tourist-oriented services (retail sales, restaurants, catering, etc.) which benefit from proximity to Finland and Sweden have achieved high growth rates with consumer demand rising $200 \%$ during 1993, in current prices (Hansabank, 1994). The amount of tourists to Estonia increased by 23\% in 1994, which represents a growing industrial sector. (Estonian Economics Ministry, 1995)

\section{Current Changes in Agricultural Practices}

Much of the agricultural procedures used are older and more labor intensive than those deployed in Western Europe and the USA, and thus, less productive per worker. Part of the reason lies in the plummeting numbers of productive livestock on state farms in relation to a fairly constant number of employees (Hansabank, 1994). However, unit labor production costs in terms of foreign currencies in the Baltic agricultural sectors are relatively low, so some parity will have to be established. For example, a Baltic farm laborer earned \$35 per month in 1992 (Estonian Economics Ministry, 1994). This wage was about $40 \%$ lower than the average and would be a discouragement to hiring the best-qualified workers in high-mobility labor markets. Even though Estonian average wages have doubled to about $\$ 180$ per month in the year up to March 1995 , the average gross agricultural wage was $\$ 106$ in 1994 . The wage differential serves against agricultural workers and still remains true throughout the Baltic states. Nonetheless, the general competitive condition of the agricultural sector has been good in terms of absolute lower cost of labor when compared with the rest of Western Europe. It should be noted, however, that Estonian agricultural prices exceed those in Latvia ${ }^{\text {iii }}$, Lithuania, Kaliningrad and the rest of Russia (Estonian Competition Board, 1994).

The loss of central price controls would have contributed towards Estonian prices being higher than in the less market-oriented economies. The removal of centrally-dictated price controls via Moscow enabled some private individuals to make adequate profit by selling direct in the marketplace. On the other hand, this loss of central control could help to increase output. This has been illustrated by China, that introduced a "responsibility system" to encourage higher agricultural production in 1978. This was a motivation system to encourage a rise in production above quotas, whereby individuals could sell the surplus in private markets. As a result, agricultural output in China rose 61\% during 1978 to 1984 (McMillan et al., 1989).

The Baltic trend is towards smaller and private enterprises. Lithuania, for example, has seen an explosion in personal enterprises from 15,000 in 1992 to 27,000 in July 1993. Though the number of firms employing more than 100 employees shrunk from 3,500 in 1989 to 600 in 1993 , smaller firms employing fewer than 100 staff grew from 350 to 39,000 (Lithuanian Ministry of 
Economics, 1993). Governments (such as the Estonian) have decided that it would be better to convert many of the state-owned enterprises to private ones for various reasons:

1.Political: to keep promises made in the ruling parties' manifestos in order to appease voters and power groups.

2.Economic: to convert all Soviet-style collective enterprises to make them more "manage-able".

3.Personal efficiency: to introduce more individual motivation.

4.Investment: to increase domestic and attract more foreign investment.

Obviously, these reasons are not separate, but are over-lapping with each other in many cases. Estonia has privatized the bulk of its industry. By December 1994 Estonia had sold 192 firms or nearly $80 \%$ of the value of state assets earmarked for privatization (The Economist Intelligence Unit, 1995a). For the overall privatization process, The World Bank has offered praise for the Estonian case, with 125 signed contracts worth $\$ 63.4$ million of which $30-50 \%$ went to foreign investors (The World Bank Estonian Mission Report, 1994).

\section{Agricultural Privatization}

One of the main problems facing the governments trying to privatize the agricultural enterprises is the difficulty in attracting buyers, especially because many Baltic private citizens have insufficient capital, or no access to capital. Another problem is when an enterprise would be divided during privatization, whether the subsequent owners would be able to maintain adequate economies of scale in production. Is there an optimal agricultural enterprise size for the new owners under privatization?

The pace of privatization is retarded partly by the slow legal process of transferring property rights from public hands. This process is slow because of the reliance upon restitution, and not compensation, for changing property ownership. This is natural given the low Estonian Government financial reserves, and its commitment to a balanced budget. Restitution does, however, introduce delays in privatization when attempting to hand back property to the rightful owners in a fair and just manner. The agricultural privatization in Estonia has been slower than in the industrial sectors. Few agricultural enterprises were privatized; most being small-sized meat or dairy product plants representing a small proportion of the total Estonian national agricultural production (Estonian Privatization Agency, 1994).

One view is that in a country (e.g., Estonia) with a 'market-friendly' governmental policy and a fairly well-developed regulatory system, privatization is more economically beneficial and easier to perform than under other circumstances. Privatization of enterprises that produce tradables in competitive or potentially competitive sectors (such as industry, airlines, agriculture, and retail operations) require little more than adequate attention to transparency in the transaction 
and the lifting of any inappropriate regulations or price controls. It is likely to yield solid and rapid economic benefits as long as there are not economy-wide distortions that hinder competition.

Potential foreign investors may not be buying Baltic agricultural enterprises because of possible reasons:

1.Few agricultural auction sales put up in the first place.

2. Anxiety over local ethnic unrest or relations with Russia.

3.Language or cultural problems.

4.Perceived excessively high price asked in some cases.

5.Range and/or quality of enterprises offered may be considered low.

6. Too constrained regulations or employment guarantees.

7.Poor service from Baltic marketers during privatization.

Foreign analysis has also identified structural inefficiencies within the administration of the

Baltic privatization process: "...harmful inter-agency competition, missed opportunities, poor or insufficiently analyzed transactions that might provoke a backlash against privatization" (The World Bank, 1994). The continuation of these foreign anxieties can only lead to further blockages in potential investment sources. Clearly, the availability of the products (enterprises for sale) has not been in any doubt. The next events in the market chain are towards value and satisfaction and then exchange and transaction. These sequenced tasks have to be fulfilled (Kotler, 1984). The role of marketers and capital markets must be the next link in the market chain, and their efficiency has to be assessed.

\section{Capital Formation}

The problem of low Baltic fixed capital formation slows future Baltic agricultural long-term growth, because of the:

1.low economic base and spare capital available;

2.privatization laws are incomplete in protecting private property rights, which raises investment risk;

3.state-owned enterprises generally have less work incentive and access to capital to carry out investment plans;

4.banks are extremely risk-averse and take very short-term views;

4.individual people have little collateral (no large private assets);

5.agricultural entrepreneurs are inexperienced in running private enterprises and writing business plans for credit requests;

6. poor international information and investment flows.

These problems also exist in many of the ex-USSR and lesser-developed states. One 
tautological fallacy is that of a Catch-22 situation: a country cannot attract foreign capital because it is poor, and it is poor because it cannot attract foreign capital. More to the point, however, is how potential investors can be convinced to expect higher marginal return on their investments by investing in these agricultural enterprises. That is, how to convince them that they can expect higher profits, irrespective of whether a country is poor or rich. For those poorer countries with large agricultural sectors, the problem is partly within the previous circular logic. The crux of the fundamental problem is how to break out of this vicious circle.

The main solution has been to readjust efforts to other more profitable markets. For the Estonian case as an example, international communications and marketing skills need to be modernized to attract more customers for its produce and more foreign investors. It is essential that the Government should take the initiative in communicating the (Estonian) investment opportunities overseas. This has been done by the Estonian government, e.g. by publishing advertisements in foreign newspapers for forthcoming privatization auctions. Such a market move is evident in the national drive towards privatization.

The Baltic target is to open up the foreign markets by removing tariffs and quotas. For the Baltics, their free trade association with the European Union - as of January 1, 1995 - is key to increasing the free-flow of goods for Baltic agricultural exports. This is coupled with timely export of these goods meeting Western quality standards, while maintaining competitive prices. Moreover, the association agreements with the European Union that the Baltics signed on June 12, 1995 add a political dimension and set forth the prospect of European Union membership at a later date. ${ }^{\text {iv }}$ This membership is particularly significant since the Baltics' key trading partners Finland and Sweden joined the European Union on January 1, 1995.

Agricultural enterprises usually will not have the international contacts or advanced management skills to seize the international market opportunities. Utilizing resources to gain competitive advantage within the market is important for long-term business prosperity (Porter, 1980). Baltic wages and regulations are very low compared with Western European levels; this is an area for competitive advantage. Balanced against this advantage are the disadvantages of unfavorable management attitudes/skills or lack of capital to change production patterns. Estonian prices do not necessarily give it an advantage within the Baltic area (Estonian Competition Board, 1994).

The fundamental alternatives (Porter, 1980) are to:

1.lower costs within the market (Baltics are not a big market);

2. differentiate/change the product range offered;

3.focus more on the Western markets;

4.leave the agricultural sector (not likely to be politically acceptable given local unemployment conditions). 
One of the "fixes" chosen by the Baltic countries has been a program of investment in farming machinery, which has resulted in an increased flow of imports. Estonian imports of machinery and capital equipment went up as percentage of total imports from $17.7 \%$ in 1993, to $19.4 \%$ in 1994 . This is forecast for above $20 \%$ in 1995 . The majority of the trade gap lies in the import of capital goods and machinery; but some of this capital investment holds hopes for the rejuvenation of the Estonian agricultural sector.

The problem of the projected trade deficit of $\$ 450 \mathrm{~m}$ in 1995 (The Economist Intelligence Unit, 1995b) for Estonia cannot be reversed in the short-run by a turnaround of the agricultural sector itself. But agriculture holds promise as one of the sectors that can break from the legacy of the past and emerge as a competitive and efficient local industry. Any suitable long-term strategy would be probably to stay out of agricultural basic foodstuffs and concentrate on national comparative advantage, e.g., processed value-added foods. This would be more positively income elastic, but may not be politically acceptable.

Many Baltic firms have low capital bases and poor international connections, especially in the agricultural sector. So Baltic groups (Governments and Chambers of Commerce) have to contact the institutions in the West to gain international market share and foreign investment. Thus, Estonia's exports to neighboring Finland shot up form 2.3\% in 1991 to $21.1 \%$ in 1992 and reached a relative plateau at $18 \%$ in 1994. Its trade deficit with Finland is large as imports are twice as large as exports. Finland remains Estonia's largest and nearest Western European trading partner. This presumes some market access without excessive hindrances of quotas, tariffs or other barriers to trade. These have to be negotiated by the representative governments.

Applications for long-term credit and technical assistance from international financial bodies such as the EU, GATT, The World Bank and the IMF can only be done from the central national level. Some of the international investment will be spent in portfolio or direct investment as purchase of Baltic agricultural enterprises. Some spending will go on infrastructure modernization, such as staff training and international liaison, and operational technology, e.g., modern telecommunications and computer databases to raise capital and capture more foreign agricultural market shares.

\section{Areas for Proposed Agricultural Improvements}

There are areas where improvements can be made to benefit the agricultural sector. Such changes represent a network of interrelated and connected parts that can be represented in a Value Chain (Porter, 1980). It is not to say that the marginal return from improvements will be the same in all areas, but each of these areas represent a part of the economy that directly influence performance in other connected parts. Some of the amendments proposed in certain areas are 
essentially long-term in nature. The complete benefit is therefore viewed as the sum total of all the value-added improvements.

\section{Privatization}

Some of the solution for the problem of declining agricultural investment and sales lies in privatization. This assumes that the private property rights are adequately defined, and housing can be released as loan collateral to secure additional investment funds for local agricultural entrepreneurs. As already stated in section 3, the speed of the privatization process is generally slow, but that seems to be symptomatic of the transition economies and problems of property rights whilst serving equity and efficiency. The filing of many claims on the property for restitution to "proper" owners will slow the privatization process. The optimum selling-off process itself has to be determined, as well as the medium of transfer (vouchers, shares or cash) and the target recipients (e.g., the whole nation or workers within the enterprise).

One view of privatization prefers a more "hands-off" Governmental approach, involving less central intervention, with enterprises sold "as is" ideally for cash. Small and medium-size competitive state-owned enterprises that can be sold through competitive bidding should be sold "as is", at the best price possible and as quickly as possible. The costs of delay are high, including potential deterioration of assets, loss of investor interest, and opportunity for opposition to coalesce.

\section{Government}

New laws and Governmental policies are needed to enforce the moves towards properly-managed private agricultural enterprises. Definition and protection of private property rights are prime requirements within this area; adequate management skills are another prerequisite. An obstacle to securing a bright agricultural future investment is the lack of a completely developed economic infrastructure, particularly transport and communications. Road, railways and seaports have to be upgraded. The Baltic States' renovation of Muuga (Estonia), Ventspils (Latvia) and Klaipeda (Lithuania) ports are large and long-term capital projects that require central management and finance, with a large element of Government initiative and international financial support.

\section{Financial Sector}

The Government and Central Bank authorities could inject more money into the economy through the creation of more private property as collateral. If this money supply increase geared towards uses to increase domestic production investment, the growth rate of GDP would accelerate. On the other hand, where a large portion of the additional capital injection is lost to the 
domestic economy as an international leakage on imported consumer goods or services, promoting domestic investment will be harder to achieve.

State agricultural banks exist in the Baltics, such as Lithuania's, but transfer of state funds to the new private farm enterprises has sometimes been a problem. Much of the flow of capital to the private agricultural sector cannot occur successfully without adequate training of central bank staff. Investment risks have to be properly analyzed, and strong controls on the emission of state funds are needed to prevent significant losses through fraud or incompetence.

Private banks similarly have a role to play and could support suitable loan applications within the private agricultural sector. As has been mentioned, the privatization process allows the freeing up of collateral for use in gaining credit. Training of staff to assess agricultural business plans and credit risk fairly will be required in order to encourage enterprise. Significant moves away from short-term sure investment turnarounds, towards longer-term investment in domestic agricultural investment opportunities are needed to expand the Baltic economies.

\section{Environment}

One of the main casualties is likely to be the natural environment itself, as unregulated and uninformed production methods may lead to major ecological damage. Uncontrolled production processes can easily lead to a market breakdown as the externalities of damage to public goods (land, air, water) are not properly accounted. Some of the cost are in the form of damage to farmland and the nature from excessive nitrogen levels. One study in the central Baltic stated: "The main sources of nitrogen are the instantaneous leakage of nitrogen from drained mires and farmers' application of nitrogen fertilizer and manure" (Gren, 1992).

\section{Education}

Education will be necessary to promote the efficient use of the new capital and resources, and this requires initiative and long-term vision from the state. The running, and longer-term planning, of the newly-privatized agricultural enterprises require training and experience that may not necessarily be commensurate with past experience in collective enterprises. Modern production techniques have to be utilized in order to raise productivity. Private entrepreneurs have also to identify investment opportunities within the international market; this will require greater communication skills, and a drive towards establishing wider market contacts.

\section{Marketing in a Changing World}

It has long been proposed (Ansoff, 1957) that there are four basic strategies for wider marketing: 
1.Market penetration.

2. Market development.

3.Product development.

4.Diversification.

Given the present availability of human and natural resources, new market development seems to be the more rational choice. Developing a new agricultural foodstuff range for the Baltic market is one option, but with its current lack of effective buying power, foreign markets would seem more advantageous. One of the basic challenges facing a country that is primarily concerned with developing its economy is that of marketing. As emphasized in the preceding section, work skills have to be developed, training of advanced agricultural production techniques, management and marketing skills are essential if this sector is to expand. Planning skills in isolation are useless unless they are put into practice, i.e., a plan is worthless unless it degenerates into work (Drucker, 1973). Courses in fundamental resource management and financial services skills are essential for needed resources and capital to flow.

The change from the old view of minimizing costs and risk, to promoting investment and increased wealth, will be part of a slow Gestalt-type shift in the mentality of the agricultural and financial communities. One view is that many of the new Baltic managers in the urban enterprises are generally young and more receptive to modern management techniques. This is often the case in Estonian banks and financial services, and is shown in the youth of the Estonian political leadership. ${ }^{v}$ Agricultural managers in rural areas would often be likely to be less attuned to advanced management practices either because of age or poor access to local agricultural training colleges. How to reach these key people to disseminate needed management and marketing skills will continue to be a major problem.

Given the commitment to privatization, the submission and writing of business plans for marketing strategies will be essential. Their proper recognition as attractive business propositions from private enterprises is a major requirement. Marketing, and primarily training of people to recognize and properly assess investment opportunities, will be a key factor (Kotler, 1984). Entrepreneurship is an essential skill, and marketing knowledge has to be cultivated to a more international view if the agricultural sector is to develop successfully.

The upgrading of agricultural produce to meet international standards and tastes will be required. This is so with the basic staple food and agricultural products, which have low income elasticity of demand and face many substitutes from other competing countries. One possible view is to look at basic foodstuffs within an appropriate product-life cycle. Goods such as cabbage, potatoes and carrots have to be re-assessed as investment areas once they have reached a demand plateau. Such traditional goods may have been faced with declining demand in a stagnating market - an example of a "dog" product (Hedley, 1977). 
This will be another example of targeting the market according to "focus" (Porter, 1980). A vital opportunity lies for economies wishing to target "niche markets" where there is escalating demand. Other goods and markets, which have higher and increasing international demand, should be selected and attacked. Products having a positive income elastic demand should be considered.

\section{.7. Summary and Conclusions}

The Baltic states move towards private enterprise, while their agricultural economic structure faces significant upheavals. Within these nations in transition, and in similar countries in economic crises, will come opportunities. The attraction of foreign interest, investment and skills, will create new market opportunities. Renewed investment is essential for raising the performance of the agricultural sector; training new production and management skills is part of this investment. Finding different products, making new contacts in growing markets, and targeting different customers will be inevitable.

A stronger economic base, built on increased domestic capital formation, will raise productivity. Training and education are primary parts of this social investment which will be required to raise agricultural growth and economic growth in general. The development would be a value-chain of connected activities that would still be led by the central authorities, in the spheres of education, legislature, finance and logistics (with international assistance where necessary). International financial and technical assistance will necessary at the appropriate areas and stages. Thus, the Government and its agencies continue to have a critical role in aiding agricultural development. Such leadership would be helped by a clear development strategy that defines concerted action, and not destructive rivalry between related governmental economic agencies.

The macroeconomic improvements have to be founded on an essential long-term development vision and plan of the economic infrastructure. It would then be likely that the Baltic economies and their agricultural sectors in particular can re-align themselves successfully to achieve focus in the international markets. It is hoped that some proposals within Estonia can be of help when applied to other regions. For the problems dealt with in this paper are not unique to Estonia and the Baltic States, but exist in many of the Central European and ex-USSR states.

\section{NOTES}

i. Yen Yee Chong was a Visiting Professor at Tallinn Technical University at the time of writing this paper. M. Peter van der Hoek is an Associate Professor of Economics at Erasmus Public Law and Economics Center (EPLEC), Erasmus University Rotterdam. 
ii. According to The Economist Intelligence Unit (1995b) agriculture and forestry accounted for approximately 10\% of GDP in Estonia (1993), 10\% in Latvia (1994) and 26\% in Lithuania (1992). The latter number, however, is out of date due to dramatic changes in recent years. In 1994 agriculture accounted for only 7\% of Lithuania's GDP (Tamosiunas and Vilkas, 1995).

iii.The Estonian Competition Board's statistics indicate that Latvian agricultural prices - like Estonian prices - exceed those in other parts of the region. Statistics provided by the Estonian Ministry of Agriculture, however, show that Latvian agricultural prices as of June 1, 1995 are surprisingly low.

iv.Before the association agreements can come into effect they must be ratified by all 15 European Union members and the three Baltic parliaments.

v. When the Laar government took office, the Prime Minister was 32 years old, while several cabinet ministers were younger than 30 years.

\section{REFERENCES}

Ansoff H.I., Strategies, Harvard Business Review, Sept-Oct 1957.

Drucker P., Management: Tasks, Responsibilities, Practice, New York 1973.

Estonian Competition Board, ERIKA Report, Tallinn June 1994.

Estonian Economics Ministry, Estonian Economic Survey, Tallinn 1994.

Estonian Economics Ministry, Economics Handbook 1994-5, Tallinn 1995.

Estonian Privatization Agency, Privatization in Estonia: Summary, Tallinn 1994.

Gren I-M., Benefits from restoring Wetlands for Nitrogen abatement, Beijer Institute, Royal Swedish Academy of Sciences, Paper ser. 14, 1992.

Hansabank, Estonian Economy, Report Quarter 1, Estonia, Tallinn 1994.

Hedley B., Diversification Strategies, Long Range Planning, Feb. 1977.

Karnite R., Dovladbekova I., Abele D., Gulans P., Bruvelis A., Bernans A., Vitkovskis R., Why and where to invest in Latvia?, Riga 1995 (mimeo).

Kotler P., Marketing Management, London 1984.

Lithuanian Ministry of Economics, Baltic Review, Quarter 4, Vilnius 1993.

Lugus O., Vitsur E., Why and where to invest in Estonia?, Tallinn 1995 (mimeo).

McMillan J., Whalley J., Zhu L., Impact of China's Economic Reforms on Agricultural Productivity Growth, Journal of Political Economy 97 (4), 1989.

Porter M., Competitive Advantage, New York 1980.

Tamosiunas R., Vilkas E., Why and where to invest in Lithuania?, Vilnius 1995 (mimeo).

The Economist Intelligence Unit (1995a) Baltic Republics: Estonia, Latvia, Lithuania, 1st quarter, 
London 1995.

The Economist Intelligence Unit (1995b) Baltic Republics: Estonia, Latvia, Lithuania, 2nd quarter, London 1995.

The World Bank, Estonian Mission Report on Finance and Privatization, (not general circulation), May 23-26, 1994. 